\title{
Weight and Lenght of Digestive Organs of Super Native Chickens Fed of Amorphophallus companulatus Tuber Flour
}

\author{
D. T. Tabun', T. A. Y. Foenay ${ }^{2}$, M. D. S. Randu ${ }^{2}$, T. N. I. Koni ${ }^{1 *}$ \\ ${ }^{1}$ Program Studi Teknologi Pakan Ternak, Jurusan Perternakan, Politeknik Pertanian Negeri Kupang \\ ${ }^{2}$ Program Studi Produksi Ternak, Jurusan Perternakan, Politeknik Pertanian Negeri Kupang \\ Jl. Prof. Dr. Herman Yohanes, Lasiana, Kelapa Lima, Kota Kupang, 85011, NTT , Indonesia \\ * Corresponding Author: Indahkoni@gmail.com
}

\begin{abstract}
The purpose of this study was to examine the use of Amorphophallus companulatus (AC) tuber flour in feed on the weight and length of the digestive organs of super-native chickens. This research was conducted for 8 weeks. The experimental design used was a completely randomized design (CRD) with 4 treatments and 5 replications $(\mathrm{P} 0=$ feed without $\mathrm{AC}$ tuber flour, $\mathrm{P} 1=$ feed containing $5 \%$ AC tuber flour, $\mathrm{P} 2=$ feed containing AC tuber flour $7.5 \%$, and $\mathrm{P} 3=$ feed containing $10 \% \mathrm{AC}$ tuber flour). The results showed that the use of AC tuber flour in the super free-range chicken feed had a very significant effect $(\mathrm{P}<0.01)$ on the weight and length of the small intestine and significantly $(\mathrm{P}<0.05)$ on pancreatic weight, but had no effect $(\mathrm{P}>0.05)$ against gizzard. It was concluded that $\mathrm{AC}$ bulbs could be used up to $10 \%$ in super-free-range chicken feed. the use of AC tuber flour as much as $7.5 \%$ in super free-range chicken feed resulted in the highest intestinal weight, intestinal length, and pancreas weight.
\end{abstract}

Key words: Amorphophallus campanulatus, crossbred native chicken, digestive organs

\section{INTRODUCTION}

Corn is the main source of energy for poultry. Fifty-one percent of the national corn is intended for the needs of the feed (Swastika et al., 2011), and for the domestic needs, corn is imported from other countries. The gap in production and demand for corn will have an impact on the price of animal feed which is likely to increase because it is necessary to find alternative feed for energy sources. The tubers of Amorphophallus campanulatus (AC) are one of the alternative energy sources for poultry feed.

Amorphophallus campanulatus is a type of tuber, which grows wild, or is not cultivated. Tuber of AC contains gross energy 3570.60 $\mathrm{kcal} / \mathrm{kg}$, crude protein $7.33 \%$, crude fiber $10.18 \%$, and crude fat by $1.4 \%$ (Koni et al., 2015), phosphorus-34 mg/100 g, and calcium $50 \mathrm{mg} / 100$ $\mathrm{g}$ (Ravi et al., 2009). In addition as a source of energy, tubers of Amorphophallus contain glucomannan. Glucomannan extracted from amorphophallus serves as a prebiotic so it can improve the digestive system and improve the performance of the chicken (Perdinan et al., 2019).

A healthy gastrointestinal tract is characterized by the development of the weight and length of the gastrointestinal tract, as well as the development of the villi are optimal so that it can optimize the absorption of the nutrients that will help increase the live weight of chicken (Pertiwi et al., 2017). Information on utilization of flour AC (Amorphophallus campanulatus) in the feed super chicken has not been done because it is then carried out this study to assess the weight and length of the digestive organs chicken super that give feed containing air conditioning tubers.

\section{MATERIALS AND METHODS}

\section{Feeding Experiment}

The tubers of Amorphophallus companulatus (AC) were taken from Manamas Village, Naibenu District, North Central Timor Regency, East Nusa Tenggara (NTT). AC tubers were washed with clean water to remove dirt from the tuber skin then sliced with a thickness of $2 \mathrm{~cm}$ and dried in the sun for 2-3 days. The dried tubers were ground with a disk mill with a sieve size of $1.5 \mathrm{~mm}$. Then AC tuber flour is mixed with other feed ingredients such as yellow corn, fine bran, vegetable oil, fish meal, soybean meal, dicalcium phosphate, limestone, vitamin, and mineral premix. The nutrient content of the ingredients for the ration is shown in Table 1. 
Table 1. Nutrient contents of raw materials of the rations

\begin{tabular}{lcccccc}
\hline \multirow{2}{*}{ The raw material } & \multicolumn{7}{c}{ Nutrients content of ingredients } \\
\cline { 2 - 7 } & $\mathrm{EM}(\mathrm{Kcal} / \mathrm{kg})$ & $\mathrm{CP}(\%)$ & $\mathrm{CF}(\%)$ & $\mathrm{EE}(\%)$ & $\mathrm{Ca}(\%)$ & $\mathrm{P}$ \\
\hline Yellow corn* & 3370 & 8.6 & 2.6 & 2 & 0.02 & 0.1 \\
\hline Tuber AC flour & $3570.6^{* *}$ & $7.33^{* *}$ & $10.18^{* *}$ & $1.40^{* *}$ & $0.05^{* * *}$ & $0.034^{* * *}$ \\
Bran smooth $^{*}$ & 1630 & 8.0 & 0.4 & 12 & 0.12 & 0.21 \\
Vegetable oil $^{*}$ & 9000 & 0 & 0 & 0 & 0 & 0 \\
Soy bean meal $^{*}$ & 2230 & 44 & 0 & 0 & 0.29 & 0.27 \\
Fish meal $^{*}$ & 1936 & 39.05 & 8.8 & 5.63 & 1.76 & 1.32 \\
Dicalcium phosphate $^{*}$ & 0 & 0 & 0 & 0 & 22 & 18.7 \\
Limestone $^{*}$ & 0 & 0 & 0 & 0 & 39.4 & 0.09 \\
\hline
\end{tabular}

Source: * NRC (1994); **(Koni et al. 2015); ***Ravi et al. (2009)

The feed was formulated with a crude protein content of $21.58-21.90 \%$ and metabolic energy of $3001.39-3015.43 \mathrm{Kcal} / \mathrm{kg}$ according to the needs of the super-free-range chicken in the starter phase according to the opinion (Sartika, 2016). All feed ingredients were weighed according to the formulation and mixed until homogeneous. A homogeneous feed mixture was set, pellets were made using a pelletizer machine, then the pellets were dried in the sun to dry for a day. The dried pellets were then molded into granules using a crumbling machine. The complete nutrient composition and formulation of the treatment feed are presented in Table 2.

Table 2. The formulation and nutrient content of feed treatment

\begin{tabular}{lcccc}
\hline \multirow{2}{*}{ Raw material } & \multicolumn{4}{c}{ Treatment $(\%)$} \\
\cline { 2 - 5 } & P0 & P1 & P2 & P3 \\
\hline Yellow corn & 50.45 & 45.00 & 42.50 & 40.00 \\
Tuber AC flour & - & 5.00 & 7.50 & 10.00 \\
Rice bran refined & 5.00 & 5.50 & 4.70 & 5.00 \\
Vegetable Oil (Lavenia) & 5.00 & 5.00 & 5.00 & 5.00 \\
Fish meal & 10.00 & 10.00 & 10.00 & 10.00 \\
Soybean meal & 25.70 & 25.65 & 26.45 & 26.15 \\
DL-Metheonine & 0.30 & 0.30 & 0.30 & 0.30 \\
L-Lysine HCl & 0.60 & 0.60 & 0.60 & 0.60 \\
Dicalcium phosphate & 2.40 & 2.40 & 2.40 & 2.40 \\
NaCl (salt) & 0.25 & 0.25 & 0.25 & 0.25 \\
Vitamin mineral premix & 0.30 & 0.30 & 0.30 & 0.30 \\
\hline Total & 100 & 100 & 100 & 100 \\
\hline & Nutrient content of the feed treatment & & \\
\hline ME (Kcal/kg)* & 3015.43 & 3001.39 & 3010.09 & 3013.31 \\
Crude Protein (\%)** & 21.83 & 21.58 & 21.90 & 21.72 \\
Crude Fat (\%)*** & 4.71 & 4.66 & 4.53 & 4.46 \\
Crude Fiber (\%)*** & 7.63 & 7.10 & 6.43 & 5.90 \\
Ca (\%)** & 1.11 & 1.15 & 1.21 & 1.11 \\
P (\%)** & 0.71 & 0.88 & 0.84 & 0.73 \\
\hline
\end{tabular}

Description $\mathrm{P} 0=$ Feed without $\mathrm{AC}$ tuber flour (control), $\mathrm{P} 1=$ Feed with $\mathrm{AC}$ tuber flour $5 \%, \mathrm{P} 2=$ Feed with $\mathrm{AC}$ tuber flour to $7.5 \%, \mathrm{P} 3=$ Feed with AC tuber flour $10 \%$.

* The results of the calculation, ** the Results of the laboratory analysis of chemical and feed Animal Husbandry, UNHAS. *** The results of the laboratory analysis nutrition and feed, Politani Kupang.

\section{Chicken Experiment}

Five (5) replications, each using 7 chickens. Feed and drinking water provided add libitum. Day old chicken of Supertype JOPER (Jowo Super) SRF produced by CV. Sumber Rejeki Farm (Kediri) has as many as 200 heads (male and female) with an average weight of $55.37 \mathrm{~g} / \mathrm{head}$. At the age of 8 days, 140 chickens were taken with an average weight of 96.26 $\mathrm{g} / \mathrm{head}$ and randomly assigned to four feed treatments with 5 replications, each replicates using 7 chickens. Feed and drinking water were given ad libitum.

\section{Data Collecting}

At the end of the study, 2 chickens were taken from each experimental unit whose body 
weight was close to the average body weight of the treatment group to be slaughtered and data on their digestive organs were taken. Slaughter was carried out at week 8 . Chickens must be fasted for 8 hours before being slaughtered. The slaughtered chicken is cleaned and put into hot water with a temperature of $60-70^{\circ} \mathrm{C}$, then separated from the carcass and non-carcass (feather, blood, digestive organs). The digestive organs are separated into several parts such as the Gizzard, the small intestine, and the pancreas. Weighing the digestive organs that have been separated using a digital scale with a capacity of $3000 \mathrm{~g}$. The length of the small intestine was measured using a measuring tape $(\mathrm{cm})$.

\section{Research Design}

This study used a completely randomized design (CRD) with four treatments with five replications, in each replication consisting of seven chickens. The treatments in this study were as follows.

P0: Without AC tuber flour (control)

P1: $5 \%$ AC tuber flour

P2: $7.5 \%$ AC tuber flour

P3: $10 \%$ AC tuber flour

\section{Variable Observations and Data Analysis}

Variable observations included the length of the small intestine obtained by measurement using a tape measure, and weight data of the digestive organs, namely in the small intestine, the pancreas, and gizzard obtained through weighing (Pertiwi et al., 2017). The data obtained were analyzed using analysis of variance (ANOVA) and if there was an effect, it was continued with Duncan's Multiple Range Test (Gasperz 2006).

\section{RESULTS AND DISCUSSION}

\section{Weight of Small Intestine}

The weight of the small intestine in this study ranged from 29.92 to $52.80 \mathrm{~g}$ or a relative weight of 4.6 to $6.2 \%$. Higher than the research of Ermawati et al. (2019) which stated that the relative weight of the small intestine in super native chickens given fermented papaya leaves ranged from 3.19 to $3.70 \%$. Based on the analysis of variance, the use of AC tubers in the feed had a very significant effect $(\mathrm{P}<0.01)$ on the weight of the small intestine of super-free-range chicken. It was seen that the average weight of the small intestine in chickens fed with feed containing AC tubers was higher than the treatment without $\mathrm{AC}$ tubers.

This is probably because AC tubers contain glucomannan which can function as a prebiotic so that non-pathogenic microorganisms in the digestive tract can develop properly because they get nutrients in the form of glucomannan, and a good balance of microorganisms in the digestive tract is guaranteed which in turn increases nutrient absorption. Ricky et al. (2020) stated that prebiotics is undigested carbohydrates such as fructooligosaccharides (FOS), galactooligosaccharides (GOS), and mannanoligosaccharides (MOS). Amorphophallus tubers contain glucomannan which can be used as a prebiotic and has a good effect on the growth of broiler chickens (Perdinan et al., 2019). Mangisah et al. (2018) stated that the administration of a synbiotic (a mixture of Lactobacillus casei and glucomannan) glucomannan from Amorphophallus plants can increase the length of the small intestine in ducks.

Table 3. The use of AC tuber starch in the feed on the weight and length of the small intestine, the weight of the gizzard and pancreas super chicken

\begin{tabular}{lccccc}
\hline \multirow{2}{*}{ The parameters of the } & \multicolumn{4}{c}{ Treatment } & \multirow{2}{*}{ P-Value } \\
\cline { 2 - 5 } & P0 & P1 & P2 & P3 & \\
\hline $\begin{array}{l}\text { Weights of the small } \\
\text { intestine }(\mathrm{g})\end{array}$ & $29.92 \pm 5.44^{\mathrm{c}}$ & $43.10 \pm 5.29^{\mathrm{b}}$ & $52.80 \pm 9.49^{\mathrm{a}}$ & $46.12 \pm 4.34^{\mathrm{ab}}$ & 0.000 \\
$\begin{array}{l}\text { Length of the small } \\
\text { intestine (cm) }\end{array}$ & $112 \pm 8.47^{\mathrm{b}}$ & $114.3 \pm 17.32^{\mathrm{b}}$ & $140.50 \pm 17.96^{\mathrm{a}}$ & $118.10 \pm 6.19^{\mathrm{b}}$ & 0.016 \\
$\begin{array}{l}\text { Weight of gizzard }(\mathrm{g}) \\
\text { Weight of the pancreas } \\
\text { (g) }\end{array}$ & $39.08 \pm 11.02$ & $40.38 \pm 8.37$ & $41.30 \pm 2.37$ & $36.42 \pm 4.70$ & 0.747 \\
\hline
\end{tabular}

Description: the average \pm SD standard deviation, ${ }^{\mathrm{a}, \mathrm{b}, \mathrm{c}}$ superscripts in the same row indicate a significant difference $(\mathrm{P}<0.05)$ 
The treatment using AC tubers at the level of $7.5 \%$ in the feed resulted in the highest small intestine weight. AC tubers contain glucomannan which functions as a prebiotic, and this prebiotic causes a good balance of microorganisms in the digestive tract so that nutrient absorption is higher and has a positive effect on body weight. Kim et al. (2011) stated that administration of $0.05 \%$ mannan oligosaccharides increased the population of Lactobacillus and suppressed the population of pathogenic bacteria such as Escherichia coli and Clostridium perfringens in the ileum and ultimately resulted in higher body weight in broiler chickens. The weight of the small intestine in this study was by bodyweight, the lower the body weight, the lower the intestinal weight, the body weight in each treatment $\mathrm{P} 0, \mathrm{P} 1, \mathrm{P} 2$, and $\mathrm{P} 3$ was $655.1 \pm 89.17,784.9 \pm 73,41,859.2 \pm 40.16$, and $809.0 \pm 62.04 \mathrm{~g}$. This statement is supported by Amrullah (2016) that the length and weight of various parts of the digestive tract were influenced by live weight.

\section{Length of Small Intestine}

The length of the small intestine in this study ranged from $112-140.5 \mathrm{~cm}$. Kim et al. (2011) stated that the administration of prebiotic mannan oligosaccharides resulted in a broiler chicken intestine length of $177.12 \mathrm{~cm}$ and a bodyweight of $2837 \mathrm{~g} / \mathrm{head}$. This difference is due to differences in body weight. Yang et al. (2013) stated that the higher the live weight, the longer the small intestine.

Based on the analysis of variance, the level of AC tuber administration had a very significant effect $(\mathrm{P}<0.01)$ on the length of the small intestine. This is because AC tubers contain glucomannan which functions as a prebiotic and affects the increase in the population of good microorganisms in the digestive tract so that the absorbed nutrients were higher. The length of the intestine was getting higher so that the area for nutrient absorption was wider and ultimately resulted in higher body weight. Body weights were $655.1 \pm 89.17,784.9 \pm 73.41,859.2 \pm 40.16$, and $809.0 \pm 62.04 \mathrm{~g}$, respectively, in treatments $\mathrm{P} 0$, P1, P2, and P3. Houshmand et al. (2012) stated that the length of the small intestine in broiler chickens given prebiotics was higher than without prebiotics, namely $187 \pm 4.5$, and $186 \pm 6.0$, respectively. Ibrahim, (2008); Yang et al. (2013) stated that the length of the small intestine is positively correlated with body weight, the higher the body weight, the longer the small intestine.
In the $\mathrm{P} 3$ treatment (7.5\% AC tubers), the length of the small intestine was significantly higher $(\mathrm{P}<0.05)$ than the other treatments. This was probably because the increase in body weight and live weight of chickens in the feed treatment at the AC tuber level was $7.5 \%$ higher than the other treatments, namely $103.9 \mathrm{~g} / \mathrm{head} /$ week and $859.2 /$ head. The increase in the body weight and live weight of chickens in this study was followed by an increase in the length of the intestine. This statement is supported by Menoh et al. (2018) which state that if there was an increase in body weight it will be followed by an increase in intestinal length.

\section{Weight of Gizzard}

The weight of the gizzard in this study was $36.42-41.38 \mathrm{~g} / \mathrm{head}$ or relative weight of 4.5 $5.9 \%$. The results of this study have a higher gizzard weight than the results of the research by Herlina and Ibrahim (2019) which reported that the relative weight of the gizzard of super-freerange chicken was $2.56-3.25 \%$. Leke et al. (2019) stated that the gizzard weight was 22.5-28.9 $\mathrm{g} /$ head in native chickens fed coconut oil in the ration.

Based on the analysis of variance, it can be seen that the provision of AC tubers had no significant effect $(\mathrm{P}>0.05)$ on the weight of the gizzard of super-free-range chickens. This is because the performance of the gizzard in breaking down or pulverizing the feed is relatively the same in each treatment, besides that the form of the feed is the same, namely crumble so it does not affect the difference in the gizzard. The increase in the weight of the gizzard is in line with its performance, so the higher the performance, the more the weight of the gizzard will increase, and vice versa. Sumiati et al. (2003) stated that the gizzard served to reduce the size of the feed particles so that the harder the gizzard works, the more it increased the weight of the gizzard. Leke et al. (2019) stated that the particle size of the gizzard affected the weight of the gizzard. The average gizzard weight in this study was $36.42-$ $41.30 \mathrm{~g}$.

\section{Weights of Pancreas}

The weight of the pancreas in this study ranged from 1.68 to $2.96 \mathrm{~g} /$ head after being compared with body weight, the relative weight of the pancreas ranged from 0.26 to $0.38 \%$. The results of this study are almost the same as those of Ermawati et al. (2019) that the relative weight of the pancreas in super native chickens is 0.28 $0.35 \%$. 
Based on the analysis of variance, the provision of $\mathrm{AC}$ tubers in the feed had a significant effect $(\mathrm{P}<0.05)$ on the pancreatic weight of super native chickens. The content of glucomannan which can function as a prebiotic and has a positive effect on digestibility, and enzymes that can be secreted from the pancreas in the digestive tract of chickens can function properly and the performance of the pancreas increases so that the weight of the pancreas also increases. Darmawan et al. (2019) stated that the weight of the pancreas is influenced by the performance of the pancreas in secreting digestive enzymes. Treatment P0 (without AC tubers) had significantly lower pancreatic weight $(\mathrm{P}<0.05)$ than other treatments using AC tubers. The weight of the pancreas of the super-free-range chicken in this study ranged from 1.68-2.96 g. Almost the same as the results of the study of Leke et al. (2019) in super-free-range chickens fed with a basal diet with additional coconut oil, the pancreas weight was between $2.20-2.40 \mathrm{~g}$.

\section{CONCLUSION}

Based on the results of the study, it can be concluded that the use of AC tuber flour as much as $7.5 \%$ in super free-range chicken feed resulted in the highest intestinal weight, intestinal length, and pancreatic weight but the provision of AC tubers did not affect the gizzard weight of super free-range chickens.

\section{REFERENCES}

Amrullah, I. K. 2016. Nutrisi ayam broiler. Lembaga Satu Gunung Budi. Bogor:

Darmawan, I, E. Suprijatna, dan U. Armomarsono. 2019. Pengaruh frekuensi dan periode pemberian pakan terhadap bobot relatif organ limfoid ayam buras super. Jurnal Sain Peternakan Indonesia 19 (1): $10-15 . \quad$ DOI: https://doi.org/10.31186/jspi.id.14.3.30 6-311.

Ermawati, B, Sugiharto, dan H. I. Wahyuni. 2019. Bobot relatif organ pencernaan ayam kampung super yang diberi pakan fermentasi daun dan biji pepaya. Prosiding seminar Nasional: Pengelolaan sumber daya alam berkesinambungan di kawasan gunung berapi.: Univeristas Tidar. Magelang
Gasperz, V. 2006. Teknik analisa dalam penelitian percobaan. Edisi III.: Tarsito. Bandung

Herlina, B. dan W. Ibrahim. 2019. Penambahan tepung daun salam dalam ransum terhadap konsumsi ransum, bobot potong, bobot karkas dan organ dalam ayam kampung super. Jurnal Sain Peternakan Indonesia 14 (3): 259-64. DOI: https://doi.org/10.31186/jspi.id.14.3.25 9-264.

Houshmand, M., K. Azhar, I. Zulkifli, M. H. Bejo, dan A. Kamyab. 2012. Effects of nonantibiotic feed additives on performance, immunity and intestinal morphology of broilers fed different levels of protein. South African Journal of Animal Sciences 42 (1): 22-32. DOI: https://doi.org/10.4314/sajas.v42i1.3.

Ibrahim, S. 2008. Hubungan ukuran-ukuran usus halus dengan berat badan broiler. Jurnal $\begin{array}{ll}\text { Agripet } 8 & \text { (2): } 42-46 . \quad \text { DOI: }\end{array}$ https://doi.org/10.17969/agripet.v8i2.6 $\underline{15}$.

Kim, G. B., Y. M. Seo, C. H. Kim, and I. K. Paik. 2011. Effect of dietary prebiotic supplementation on the performance, intestinal microflora, and immune response of broilers. Poultry Science 90 (1): 7582.DOI:

https://doi.org/10.3382/ps.2010-00732.

Koni, T. N. I., A. Paga, R. Wea, and T. A. Y. Foenay. 2015. Nutritive value and metabolizable energy of Amorphophallus companulatus fermented by Rhyzopus oligosporus as poultry feed. Pakistan Journal of Nutrition 14 (6): 322-24. DOI: https://doi.org/10.3923/pjn.2015.322.3 $\underline{24}$

Leke, J. R., F. N. Sompie, E. Wantasen, T. Widyastuti, dan E. H. B. Sondakh. 2019. Karakteristik organ bagian dalam ayam buras yang diberi pakan minyak kelapa (Cocos nucifera ). Zootec 39 (2): 233-40.

Mangisah, I., B. Sukanto, F. Wahyono, N. Suthama, dan V. D. Yunianto. 2018. Perbaikan pakan untuk meningkatkan 
produktivitas ayam kampung super di Kecamatan Plantungan Kabupaten Kendal. Jurnal Dianmas 7 (1): 35-40.

Menoh, Y. R., N. G. A. Mulyantini, dan F. M. S. Telupere. 2018. Pengaruh penggunaan pelet daun ubi jalar ungu (Ipomoea batatas var. Ayamurasaki) terfermentasi larutan Effective Microorganism 4 (EM-4) Dalam ransum terhadap performa ayam broiler. Journal of Tropical Animal Production 19 (2): $\quad 120-38 . \quad$ DOI: https://doi.org/10.21776/ub.jtapro.2018 .019 .02 .7

National Research Council (NRC). 1994. Nutrient requirement of poultry. IX. . National Academy Press. Washington DC.:

Perdinan, A., H. I. Wahyuni, and N. Suthama. 2019. Body resistance and growth performance of broiler fed glucomannan extracted from Amorphophallus onchophyllus tuber. Tropical Animal Science Journal 42 (1): 33-38. DOI: https://doi.org/10.5398/tasj.2019.42.1.3 $\underline{3}$.

Pertiwi, D. D. R., R. Murwani, dan T. Yudiarti. 2017. Bobot relatif saluran pencernaan ayam broiler yang diberi tambahan air rebusan kunyit dalam air minum. Jurnal Peternakan Indonesia 19 (2): 60. https://doi.org/10.25077/jpi.19.2.60$\underline{64.2017 .}$.
Ravi, V., C. S. Ravindran, and G. Suja. 2009. Growth and Productivity of elephant foot yam (Amorphophallus paeoniifolius (Dennst. Nicolson ): an overview. Journal of Root Crops 35 (2): 131-42.

Ricke, S. C., S. I. Lee, S. A. Kim, S. H. Park, and Z. Shi. 2020. Prebiotics and the Poultry gastrointestinal tract microbiome. Poultry

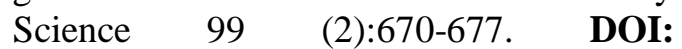
https://doi.org/10.1016/j.psj.2019.12.0 $\underline{18}$

Sartika, T. 2016. Panen ayam kampung 70 hari. Penebar Swadaya. Jakarta:

Sumiati, W. Hermana, dan A. Aliyani. 2003. Persentase karkas dan organ dalam ayam broiler yang diberi tepung daun talas (Colocasia esculenta (L) Shoott) dalam ransumnya. Media Akuakultur 26 (2): 4 10.

Swastika, D. K. S., A. Agustian, dan T. Sudaryanto. 2011. Analisis senjang penawaran dan permintaan jagung pakan dengan pendekatan sinkronisasi sentra produksi, pabrik pakan, dan populasi ternak di Indonesia. Informatika Pertanian 2 (2): 65-75.

Yang, H. M., W. Wang, Z. Y. Wang, J. Wang, Y. J. Cao, and Y. H. Chen. 2013. Comparative study of intestine length, weight and digestibility on different body weight chickens. African Journal of Biotechnology 12 (32): 5097-5100. DOI: https://doi.org/10.5897/ajb11.4014. 